\title{
Bacteriocin, Plasmid and Pectolytic Diversity in Pseudomonas cepacia of Clinical and Plant Origin
}

\author{
By CARLOS F. GONZALEZ* AND ANNE K. VIDAVER \\ Department of Plant Pathology, University of Nebraska, Lincoln, \\ Nebraska 68583, U.S.A.
}

(Received 25 July 1978)

\begin{abstract}
Pseudomonas cepacia strains of plant and clinical origin were compared with the type strains of $P$. cepacia, $P$. kingii and $P$. multivorans. Conventional biochemical tests and antibiotic sensitivity patterns supported the previous proposals of synonymy between $P$. cepacia, $P$. kingii and $P$. multivorans. However, bacteriocin production patterns, onion maceration tests and hydrolysis of low $\mathrm{pH}$ pectate agar clearly differentiated strains of clinical and plant origin into two distinct groups; these tests may therefore be helpful in epidemiological studies. In contrast, plant and clinical strains were of equal lethality to mice. Agarose gel electrophoresis indicated the presence of one or more plasmids (molecular weights $9 \times 10^{6}$ to $120 \times 10^{6}$ ) in 15 out of 16 strains of both types examined.
\end{abstract}

\section{INTRODUCTION}

Pseudomonas cepacia has been described as the causal agent in decay of onions (Burkholder, 1950). Since then, $P$. multivorans isolated from soil and $P$. kingii from clinical sources also have been described as synonyms for $P$. cepacia (Sinsabaugh $\&$ Howard, 1975; Snell et al., 1972). The synonymy of $P$. cepacia (Burkholder, 1950) and $P$. multivorans (Stanier et al., 1966) was established by Ballard et al. (1970) on the basis of indistinguishable patterns of utilization of a wide range of carbon substrates and of similar levels of molecular homology as shown by DNA-DNA hybridization. Snell et al. (1972) have, in addition, proposed that $P$. kingii (Jonsson, 1970) is a synonym of $P$. cepacia. Sinsabaugh \& Howard (1975) confirmed the synonymy of $P$. multivorans and $P$. kingii by subjecting a larger number of strains (15 of each) to a wider variety of morphological, nutritional, physiological and biochemical tests than employed in previous studies.

The importance of $P$. cepacia, $P$. kingii, and $P$. multivorans as aetiological agents of clinical infection is well documented (Bassell et al., 1970; Dailey \& Benner, 1968; Phillips et al., 1971; Taplin et al., 1971). Pseudomonas kingii strains have been reported as causing necrotizing pneumonitis (Dailey \& Benner, 1968). Pseudomonas multivorans, isolated from sputum and blood cultures, has been implicated as significant in blood infections (Phillips et al., 1971).

In view of these findings and the synonymy of $P$. cepacia with both $P$. kingii and $P$. multivorans, the question remained open as to whether $P$. cepacia of plant origin was equivalent to clinical isolates in characters not previously studied. We report here that $P$. cepacia of plant and clinical origin are distinguishable by differences in bacteriocin production, maceration of onion slices, hydrolysis of low $\mathrm{pH}$ pectate agar and the size of resident plasmids.

\footnotetext{
* Present address: Department of Plant Pathology, University of California, Davis, California 95616, U.S.A.
} 


\section{METHODS}

Bacterial strains, medium and cultural conditions. The strains used in this study (Table 1) were maintained at $4{ }^{\circ} \mathrm{C}$ on nutrient yeast extract medium (NBY; Vidaver, 1967).

Biochemical tests. Acid production from nine sugars was tested by the method of Hugh \& Leifson (1953), using Difco O-F basal medium and the ammonium salts medium of Smith et al. (1952). Results were read daily for $5 \mathrm{~d}$. Arginine dihydrolase was tested by the method of Thornley (1960). Lysine and ornithine decarboxylase activities were detected using Moeller (Difco) decarboxylase base overlaid with sterile mineral oil. Oxidase activity was tested with cytochrome oxidase test paper (PathoTec).

Assay for pectolytic activity. Cells were streaked on NBY agar, incubated overnight at $30{ }^{\circ} \mathrm{C}$, then suspended in sterile distilled deionized water and adjusted spectrophotometrically to $1 \times 10^{9}$ colony forming units (c.f.u.) $\mathrm{ml}^{-1}$. Appropriate dilutions of the suspension were made to obtain isolated colonies. Hildebrand's (1971) medium A and medium B and Cuppels \& Kelman's (1974) crystal violet pectate (CVP) medium, all of which contained sodium polypectate (Sigma), were used in testing for pectolytic activity. Hildebrand's medium A was adjusted to $\mathrm{pH} 4.9$ by adding $3.0 \mathrm{ml} 1 \mathrm{M}-\mathrm{HCl}$ to $500 \mathrm{ml}$ basal medium, medium $\mathrm{B}$ was adjusted to $\mathrm{pH} 6.9$ by adding $1.2 \mathrm{ml} 1 \mathrm{M}-\mathrm{NaOH}$ to $500 \mathrm{ml}$ basal medium, and CVP medium was adjusted to $\mathrm{pH} 7.2$ by adding $1 \mathrm{M}-\mathrm{NaOH}$ as previously described (Cuppels \& Kelman, 1974). Plates were incubated at $30^{\circ} \mathrm{C}$ for $P$. cepacia and Erwinia carotovora and at $25^{\circ} \mathrm{C}$ for $P$. fluorescens. Readings were taken at 24,48 and $72 \mathrm{~h}$. The type and extent of depression in the pectate gel were rated on a 0 - to 5 -point scale. Agar pitting was compared with the 5-point rating of E. carotovora on CVP medium.

Bacteriocin production and assay. Conditions for production were as previously described (Vidaver et al., 1972) except that, for assay, producer plates were incubated at 25 or $30^{\circ} \mathrm{C}$, depending on the experiment. All indicator strains were grown at $30^{\circ} \mathrm{C}$. The conditions for bacteriocin production in liquid were as described by Haag \& Vidaver (1974), except that incubation was at 20,25 or $30^{\circ} \mathrm{C}$ on a rotary shaker at 300 rev. min $^{-1}$, depending on the experiment. Assay plates were incubated at the temperature of production for $24 \mathrm{~h}$.

Assay for ability to macerate plant tissue. Yellow onions (Utah yellow sweet spanish) were used throughout this study. The outer scale layers were carefully removed before slicing with an alcohol-flamed knife. The onion slices, approximately 3 to $5 \mathrm{~mm}$ thick, were cut transversely through the bulb; this usually gave five to eight leaf bases. The slices were then placed in a sterile Petri dish containing two sheets of sterile Whatman no. 1 filter paper pre-moistened with sterile distilled water.

For inoculation, bacterial isolates were grown overnight on NBY agar. A bacterial suspension was then made in sterile distilled water and washed twice by centrifugation. The $A_{425}$ was adjusted to give between $10^{1}$ and $10^{9}$ c.f.u. $\mathrm{ml}^{-1}$. (The bacterial concentrations were determined using calibration curves prepared by triplicate platings on NBY agar.) Onion slices were inoculated by transverse spreading of $0 \cdot 1 \mathrm{ml}$ bacterial suspension to give between $10^{3}$ and $10^{8} \mathrm{c}$.f.u. per slice. Plates were incubated at 25 and $30^{\circ} \mathrm{C}$; readings were taken at 24,48 and $72 \mathrm{~h}$.

Determination of $L D_{50}$ in mice. Bacteria were grown overnight in NBY broth, then centrifuged $(12100 \mathrm{~g})$ and washed twice in sterile saline $[0.85 \%(\mathrm{w} / \mathrm{v}) \mathrm{NaCl}]$. The final pellet was resuspended in sterile saline and adjusted spectrophotometrically to $10^{10}$ c.f.u. $\mathrm{ml}^{-1}$. Serial twofold dilutions of the suspensions were made in sterile saline. Female Swiss-Webster mice (20 to $25 \mathrm{~g}$ ) were inoculated by intraperitoneal injection of $0.25 \mathrm{ml}$ of a bacterial dilution (four mice per dilution). Mice inoculated with saline served as a control. Animals were observed for $5 \mathrm{~d}$ after inoculation, and the $\mathrm{LD}_{50}$ was calculated by the method of Reed \& Muench (1938). A minimum of 32 animals was used per experiment.

Minimal inhibitory concentration (m.i.c.). Bacteria were grown overnight on Mueller-Hinton agar (Difco), then suspended in sterile saline and diluted to less than 2000 c.f.u. $\mathrm{ml}^{-1} ; 10 \mu 1$ was spotted on to MuellerHinton agar plates containing doubling concentrations ( 5 to $1280 \mu \mathrm{g} \mathrm{ml}^{-1}$ ) of different antibiotics, plates without antibiotic serving as controls. Plates were incubated at $30^{\circ} \mathrm{C}$ and read after 24,48 and $72 \mathrm{~h}$. The m.i.c. given is the concentration of antibiotic which prevented colony formation. The antibiotics tested were penicillin, neomycin, nalidixic acid, streptomycin, kanamycin, gentamycin, tetracycline, chloramphenicol and polymyxin B (all from Sigma), carbenicillin (Geopen, from Ffizer) and minocycline (Minocin, from Lederle Laboratories, Pearl River, N.Y., U.S.A.).

Preparation of DNA for agarose gel electrophoresis. DNA for agarose analysis was isolated by a slight modification of the method of Currier \& Nester (1976). Bacteria ( $30 \mathrm{ml}$ ) were grown in NBY to an $A_{640}$ of 0.7 , then washed twice in TE buffer $(0.05 \mathrm{M}$-Tris, $0.02 \mathrm{M}$-EDTA, pH 8.0), resuspended in $11 \mathrm{ml}$ TE buffer and treated with lysozyme (at $200 \mu \mathrm{g} \mathrm{ml}^{-1}$ ) for $40 \mathrm{~min}$ at $37^{\circ} \mathrm{C}$. Pronase B (Sigma) in TE buffer was predigested at $37^{\circ} \mathrm{C}$ for $90 \mathrm{~min}$ and then added at $500 \mu \mathrm{g} \mathrm{ml}^{-1}$ to the bacteria. After 5 min at $37^{\circ} \mathrm{C}$, Sarkosyl (ICN-K \& $\mathrm{K}$ Laboratories) was added to a final concentration of $1 \%(\mathrm{w} / \mathrm{v})$ and incubation was continued at $37^{\circ} \mathrm{C}$ for $30 \mathrm{~min}$. Shearing, denaturation and renaturation were as described by Currier $\&$ Nester (1976). After neutralization, the lysate was adjusted to $1 \mathrm{M}-\mathrm{LiCl}$. One volume of saturated phenol/1 $\mathrm{M}-\mathrm{LiCl}(1: 1$, 


\section{Table 1. Test strains}

\begin{tabular}{lccl} 
& $\begin{array}{c}\text { Strain } \\
\text { no. }\end{array}$ & $\begin{array}{c}\text { Strain designation } \\
\text { as received } \dagger\end{array}$ & \multicolumn{1}{c}{$\begin{array}{l}\text { Source of } \\
\text { isolation }\end{array}$} \\
Pseudomonas cepacia & 1 & $\mathrm{~B} 5912^{\mathrm{a}}$ & Wound \\
$P$. cepacia & 2 & $\mathrm{~B} 6566^{\mathrm{a}}$ & Blood \\
$P$. cepacia & 3 & $\mathrm{~B} 4648^{\mathrm{a}}$ & Skin exudate \\
$P$. cepacia & 4 & $\mathrm{~B} 5910^{\mathrm{a}}$ & Urine \\
$P$. cepacia & 5 & $\mathrm{~B} 4345^{\mathrm{a}}$ & Sputum \\
$P$. kingii & 6 & ATCC $25609^{\mathrm{b}}$ & Bronchial washing \\
$P$. cepacia & 7 & Hines no. $1^{\mathrm{c}}$ & Nebulizer \\
$P$. cepacia & 8 & Hines no. $2^{\mathrm{c}}$ & Nebulizer \\
$P$. cepacia & 9 & PC142 & Onion \\
$P$. cepacia & 10 & $64-22^{\mathrm{e}}$ & Onion \\
$P$. cepacia & 11 & $71-22^{\mathrm{e}}$ & Onion \\
$P$. cepacia & 12 & $72-108^{\mathrm{e}}$ & Onion \\
$P$. cepacia & 13 & $72-60^{\mathrm{e}}$ & Onion \\
$P$. cepacia & 14 & $74-34^{\mathrm{e}}$ & Onion \\
$P$. cepacia & 15 & ATCC $10856^{\mathrm{e}}$ & Onion \\
$P$. cepacia & 16 & ATCC $25416^{\mathrm{b}}$ & Onion \\
$P$. multivorans & 17 & ATCC $17759^{\mathrm{b}}$ & Soil \\
$P$. allicola & 18 & ATCC $19302^{\mathrm{b}}$ & Onion \\
$P$. aeruginosa & 19 & ATCC $17793^{\mathrm{f}}$ & Sputum \\
$P$. fluorescens & 20 & ATCC $13525^{\mathrm{b}}$ & Pre-filter tank \\
Micrococcus luteus & 21 & ATCC $4698^{\mathrm{b}}$ & Unknown \\
Erwinia carotovora & 22 & SR $204^{\mathrm{g}}$ & Potato
\end{tabular}

* Code number used for this study.

$\dagger$ Received from: a, R. Weaver, Center for Disease Control, Atlanta, Ga.; b, American Type Culture Collection (all type strains); c, S. M. Gelbarth, VA Hospital, Hines, Ill.; d, M. P. Starr, International Collection of Phytopathogenic Bacteria, University of California, Davis, Calif.; e, J. W. Lorbeer, Department of Plant Pathology, Cornell University, Ithaca, N.Y.; f, S. Berk, Department of Immunology and Microbiology, Wayne State University, Detroit, Mich.; g, A. Kelman, Department of Plant Pathology, University of Wisconsin, Madison, Wis.

$\mathrm{v} / \mathrm{v}$ ) was then stirred with the lysate for $5 \mathrm{~min}$. The aqueous phase was separated from the phenol phase by centrifuging, and DNA was precipitated by adding two volumes of $95 \%(\mathrm{v} / \mathrm{v})$ ethanol.

Agarose gel electrophoresis. Ethanol-precipitated DNA was subjected to electrophoresis in $0.7 \%(\mathrm{w} / \mathrm{v})$ agarose (ME grade; SeaKem, Marine Colloids, U.S.A.) dissolved in Tris/borate buffer ( $89 \mathrm{~mm}$-Tris, $2.5 \mathrm{~mm}$-EDTA and $89 \mathrm{~mm}$-boric acid) containing $0.1 \%(\mathrm{w} / \mathrm{v})$ sodium dodecyl sulphate (SDS). The dye solution contained $5 \%(\mathrm{w} / \mathrm{v})$ SDS, $25 \%(\mathrm{v} / \mathrm{v})$ glycerol and $0.025 \%(\mathrm{w} / \mathrm{v})$ bromophenol blue. Electrophoresis was carried out using an ORTEC Electrophoresis System (model 4200; ORTEC, Oakridge, Tenn., U.S.A.). The dimensions of the gel were $8 \cdot 0 \times 10 \times 0 \cdot 3 \mathrm{~cm}$. Sample wells were made by using a Teflon comb with 12 teeth. A $6 \%(\mathrm{w} / \mathrm{v})$ acrylamide plug of about $1 \mathrm{~cm}$ was used to prevent the agarose from slipping out of the cell. Electrophoresis was carried out at $18 \mathrm{~mA}, 40 \mathrm{~V}$ for $3 \mathrm{~h}$. Gels were stained in a solution of ethidium bromide $\left(0.5 \mu \mathrm{g} \mathrm{ml}^{-1}\right)$ for $30 \mathrm{~min}$. The DNA bands were visualized by the fluorescence from bound ethidium bromide. The gels were laid directly on the u.v. lamp filter (transilluminator C62; Ultraviolet Products, San Gabriel, Calif., U.S.A.) and photographed with a Polaroid MP-4 camera, equipped with a u.v. filter and orange (O2) filter, using Polaroid-type 665 film.

\section{RESULTS}

\section{Biochemical characteristics}

A distinguishing feature of $P$. cepacia is production of acid from a wide range of carbohydrates (Snell et al., 1972). All isolates tested (Table 1), including the type strains of $P$. kingii, $P$. multivorans and $P$. cepacia, produced acid from glucose, mannose, xylose, lactose, sucrose, maltose and mannitol, and were variable for acid from fructose. No acid was produced from rhamnose. 
Table 2. Pectolytic activity of $P$. cepacia strains on Hildebrand's medium $A$ and medium $B$

Results were scored on a 5-point scale ( 0 , no pitting; 5 , depression to bottom of plate) after 24,48 and $72 \mathrm{~h}$.

\begin{tabular}{clll} 
& \multicolumn{3}{c}{ Medium A (pH 4.9) } \\
\cline { 2 - 4 } Strain* & $24 \mathrm{~h}$ & $48 \mathrm{~h}$ & $72 \mathrm{~h}$ \\
1 & $0 \cdot 5$ & 1 & 2 \\
2 & 0 & 1 & 1 \\
3 & 0 & 0 & 0 \\
4 & $0 \cdot 5$ & 1 & 2 \\
5 & 0 & 0 & 0 \\
6 & 1 & $2 \cdot 5$ & $2 \cdot 5$ \\
7 & 0 & 0 & 0 \\
8 & 0 & 0 & 0 \\
9 & 3 & 3 & 3 \\
10 & 2 & $2 \cdot 5$ & $2 \cdot 5$ \\
11 & 2 & 3 & 3 \\
12 & 2 & 2 & 2 \\
13 & 2 & 2 & 2 \\
14 & 2 & 2 & 2 \\
15 & 2 & 2 & $2 \cdot 5$ \\
16 & 2 & 3 & 3 \\
17 & 1 & $1 \cdot 5$ & $1 \cdot 5$ \\
20 & 0 & 0 & 0 \\
22 & 0 & 1 & 3
\end{tabular}

\begin{tabular}{ccc}
\multicolumn{3}{c}{ Medium $\mathrm{B}(\mathrm{pH} 6 \cdot 9)$} \\
\hline $24 \mathrm{~h}$ & $48 \mathrm{~h}$ & $72 \mathrm{~h}$ \\
0 & 0 & 0 \\
0 & $0 \cdot 2$ & $0 \cdot 2$ \\
0 & 0 & 0 \\
0 & 0 & 0 \\
0 & 0 & 0 \\
0 & $0 \cdot 5$ & 1 \\
0 & 0 & 0 \\
0 & 0 & 0 \\
3 & 3 & 3 \\
0 & 0 & 1 \\
0 & 0 & 1 \\
0 & 0 & 0 \\
0 & 0 & 1 \\
0 & 0 & 0 \\
0 & 1 & 2 \\
0 & 1 & 2 \\
0 & 0 & 0 \\
0 & 0 & 0 \\
3 & 4 & 4
\end{tabular}

* Code numbers given for this study (see Table 1): strains 1 to 6 were from clinical sources; strains 7 and 8 were isolated from hospital equipment; strains 9 to 17 were of plant or soil origin.

\section{Pectolytic activity}

The pectolytic activity of the $P$. cepacia strains was assessed on plates containing polypectate. Strains plated on CVP medium, a selective medium for Erwinia spp., were all negative, whereas the control E. carotovora had strong pectolytic activity and caused typical deep pits in the medium.

The pectolytic activity of the $P$. cepacia strains varied with the source of isolation, the medium and the period of incubation (Table 2). Differentiation of strains by pectolytic activity was most apparent at $24 \mathrm{~h}$, with Hildebrand's media A and B. All plant strains showed moderate activity on medium A $(\mathrm{pH} 4.9)$ at $24 \mathrm{~h}$, as indicated by a wide shallow depression in the polypectate gel; only a trace of activity was shown by two clinical strains. None of the P. cepacia strains, except PC142, showed activity on medium B (pH 6.9). By $48 \mathrm{~h}$, some plant and clinically derived strains showed a progressive utilization of the pectate at the lower $\mathrm{pH}$ (medium $\mathrm{A}$ ), as indicated by wider and deeper pitting of the gel. Activity on medium $\mathrm{B}$, at $48 \mathrm{~h}$, was none to moderate; three plant strains showed weak to moderate activity, and two clinical strains showed only a trace of activity. At $72 \mathrm{~h}$, activity on medium A had increased. Only a few isolates from either source showed activity on medium B. The $\mathrm{pH}$ dependence of the pectolytic enzymes was apparent. The $24 \mathrm{~h}$ reading appeared best for strain differentiation.

\section{Bacteriocin production patterns}

All $P$. cepacia strains and the type strains of $P$. kingii, $P$. multivorans and $P$. allicola were tested for bacteriocin production on solid medium. Each strain was used as an indicator against all the other strains. Micrococcus luteus was also tested as an indicator for all strains, since this strain is susceptible to all bacteriocin groups of the plant pathogens $P$. syringae, $P$. phaseolicola and P. glycinea (Vidaver et al., 1972).

The Hines isolates (nos 7 and 8 ) enabled the clinical and phytopathogenic $P$. cepacia to 
Table 3. Bacteriocin production patterns of P. cepacia strains*

$\begin{array}{ccccc}\begin{array}{c}\text { Indicator } \\ \text { strain }\end{array} & \overbrace{1-6} & 7,8 \dagger & 9-17 & 18 \\ 1-6 & - & - & - & - \\ 7,8 & - & - & +\ddagger & - \\ 9-17 & - & - & - & - \\ 18 & - & -\S & - & - \\ 21 & ++ & +\$ & + \pm & +\end{array}$

* Production was assayed at 25 and $30^{\circ} \mathrm{C}$. Strains 1 to 6 (clinical strains) produced identical patterns; strains 9 to 17 (plant or soil strains) produced identical patterns (see Table 1 for strain numbers).

$\uparrow$ Strains isolated from hospital equipment (see Table 1).

+ All zones were clear and measured 15 to $20 \mathrm{~mm}$ from the margin of the colony.

$\S$ Strain 7 produced a turbid zone on strain 18 at $25^{\circ} \mathrm{C}$ but not at $30^{\circ} \mathrm{C}$.

be clearly differentiated; the former were negative and the latter were positive in bacteriocin production (Table 3 ). The $P$. multivorans type strain, which had previously been shown to be taxonomically equivalent to the plant isolates, was also grouped with the phytopathogenic $P$. cepacia. All strains produced bacteriocin-like activity against Micrococcus luteus. Results were the same whether plates were incubated at 30 or $25^{\circ} \mathrm{C}$, except for strain no. 7 (Table 3 ).

To test for inducibility of bacteriocins, mid-exponential phase liquid cultures of all isolates were treated with mitomycin $\mathrm{C}$. The supernatants from the treated cultures were spotted on to lawns of all $P$. cepacia strains and $M$. luteus. No indication of bacteriocin activity was detected in any combination of indicator and producer. Therefore, under our conditions, bacteriocin production in liquid culture was not detected.

\section{Onion maceration test}

Onion slices were used to test the ability of the different strains to macerate plant tissue. The clinical isolates were inoculated at $10^{8}, 10^{6}$ and $10^{4}$ bacteria per slice. The symptoms were rated on a 5-point scale for maceration, and discoloration of tissue was noted. No maceration or discoloration of tissue was observed with clinical isolates at $10^{4}$ and $10^{6}$ bacteria per slice, and only a trace of maceration and some discoloration (browning) occurred at the highest concentration tested (Table 4).

The plant strains were inoculated at $10^{8}, 10^{5}$ and $10^{3}$ bacteria per slice. At the highest concentration, tissue was completely macerated. At the lower concentrations, these isolates gave reactions ranging from 2 , with a brown-yellow discoloration, to 5 (complete maceration of tissue) accompanied by a sulphur yellow discoloration due to growth of the bacteria (Table 4). The $P$. multivorans strain caused little $(1+)$ maceration and only slight discoloration of tissue at the $10^{8}$ concentration; Pseudomonas allicola caused moderate $(3+)$ maceration and a brown discoloration of tissue, when inoculated at $10^{5}$ bacteria per slice.

\section{Determination of $L D_{50}$ in mice}

Although pectolytic activity differentiated the phytopathogenic $P$. cepacia strains from those of clinical origin, the isolates tested differed only slightly in their lethality to mice (Table 5). The $P$. aeruginosa positive control and the $P$. fluorescens negative control gave $\mathrm{LD}_{50}$ values of $9 \times 10^{7}$ and $2 \times 10^{9}$, respectively. This $\mathrm{LD}_{50}$ for $P$. aeruginosa was slightly lower than the $1 \cdot 1 \times 10^{8}$ previously reported for the strain (Berk, 1977). No deaths were observed prior to $8 \mathrm{~h}$. Diarrhoea was observed only in animals which eventually died.

\section{Minimal inhibitory concentration studies}

Since most clinical strains of $P$. cepacia are susceptible to chloramphenicol but not to antibiotics of the polymyxin group or to gentamycin (Gilardi, 1971), we examined the plant 
Table 4. Test for onion maceration by $P$. cepacia strains

Results were scored on a 5 -point scale $(0$, no maceration; $5+$, tissue completely macerated) after $72 \mathrm{~h}$.

ND, Not done.

\begin{tabular}{clccc}
\multicolumn{4}{c}{ Inoculum (c.f.u. per slice) } \\
Strain* & $10^{3}$ & $10^{4}$ & $10^{5}$ & $10^{8}$ \\
$1-8$ & ND & 0 & ND & $\leqslant 0 \cdot 5+$ \\
9 & $1+$ & ND & $3+$ & $5+$ \\
10 & $2+$ & ND & $3+$ & $5+$ \\
11 & $2+$ & ND & $4+$ & $5+$ \\
12 & $1+$ & ND & $3+$ & $5+$ \\
13 & $4+$ & ND & $5+$ & $5+$ \\
14 & $3+$ & ND & $5+$ & $5+$ \\
15 & $1+$ & ND & $3+$ & $5+$ \\
16 & $2+$ & ND & $4+$ & $5+$ \\
17 & 0 & ND & $0 \cdot 5+$ & $1+$ \\
18 & $1+$ & ND & $3+$ & $5+$
\end{tabular}

* Code numbers given for this study (see Table 1); strains 1 to 6 were from clinical sources; strains 7 and 8 were isolated from hospital equipment; strains 9 to 18 were of plant or soil origin. Strains 1 to 8 gave indistin€uishable results.

Table 5. $L D_{50}$ of $P$. cepacia strains in mice

The inoculum was injected intraperitoneally and the $\mathbf{L D}_{50}$ was determined after $72 \mathrm{~h}$.

$\begin{array}{clc}\text { Strain* } & \text { Source } & \text { LD }_{50} \\ 1 & \text { Wound } & 5 \cdot 1 \times 10^{8} \\ 2 & \text { Blood } & 4 \cdot 1 \times 10^{8} \\ 6 & \text { Bronchial } & 2.6 \times 10^{8} \\ & \text { washing } & \\ 10 & \text { Plant } & 4.2 \times 10^{8} \\ 14 & \text { Plant } & 5.4 \times 10^{8} \\ 16 & \text { Plant } & 1 \cdot 7 \times 10^{8} \\ 17 & \text { Soil } & 1.9 \times 10^{8} \\ * & \text { Code number given for this study (see Table 1). }\end{array}$

pathogens to see if they had different antibiotic susceptibility patterns (Table 6). The aminoglycoside antibiotics - kanamycin, gentamycin and neomycin - had limited activity against plant and clinical isolates. The majority of strains were resistant to polymyxin $B$, penicillin, streptomycin and carbenicillin at 640 to $1280 \mu \mathrm{g} \mathrm{ml}^{-1}$. Resistance to tetracycline was generally high (160 to $320 \mu \mathrm{g} \mathrm{ml}^{-1}$ ), except for the Hines isolates (nos 7 and 8 ) which were sensitive to less than $20 \mu \mathrm{g} \mathrm{ml}^{-1}$. However, the tetracycline derivative minocycline (7-dimethylamino-6-deoxytetracycline) was inhibitory $\left(<10 \mu \mathrm{g} \mathrm{ml}^{-1}\right)$ to all strains. Sensitivity to nalidixic acid was moderate in most strains. As expected, susceptibility to chloramphenicol was high (usually 5 to $20 \mu \mathrm{g} \mathrm{ml}^{-1}$ ).

\section{Plasmid analysis of strains}

Because of the high levels of antibiotic resistance and because many studies have shown that genetic determinants for such resistance may be carried on plasmids, experiments were initiated to detect their presence. Lysates from several strains were made and the salt/ ethanol-precipitated DNA was analysed by agarose gel electrophoresis for the presence of plasmid DNA (Figs 1 and 2). Among $P$. cepacia from clinical sources, the plasmid number ranged from 0 to 4 (Fig. 1). The Hines isolates, which differ in bacteriocin and drug sensitivity, had four plasmids ranging in size from $9 \times 10^{6}$ to $105 \times 10^{6}$ daltons (Fig. $1 j, k$ ). Almost all the onion pathogens including the type strain"(Fig. $2 d$ to $j$ ) had a common plasmid of $120 \times 10^{6}$ daltons. The $P$. multivorans type strain had a plasmid of $13 \times 10^{6}$ daltons (Fig. $2 \mathrm{~h}$ ). 
Table 6. Minimal inhibitory concentrations of antibiotics* for various strains

\begin{tabular}{crrrrrrrrrrrr}
\multicolumn{10}{c}{ Minimal inhibitory concentration $\left(\mu \mathrm{g} \mathrm{ml}^{-1}\right)$} \\
Strain & \multicolumn{10}{c}{ Pc } & \multicolumn{10}{c}{ Cb } & Nm & Sm & Nal & Km & Gm & Tc & Mc & Cm & PolyB \\
1 & 320 & 2000 & 640 & 1280 & 40 & 80 & 640 & 320 & $<10$ & 5 & $>1280$ \\
2 & 640 & 2000 & 640 & 1280 & 20 & 160 & 320 & 320 & $<10$ & 5 & $>1280$ \\
3 & 80 & 125 & 320 & $>1280$ & 80 & 40 & 160 & 320 & $<10$ & 5 & $>1280$ \\
4 & 320 & 250 & 320 & $>1280$ & 40 & 80 & 320 & 320 & $<10$ & 5 & $>1280$ \\
5 & 640 & 2000 & 640 & $>1280$ & 20 & 160 & 640 & 160 & $<10$ & 5 & $>1280$ \\
6 & 640 & 2000 & 320 & 1280 & 40 & 80 & 320 & 320 & $<10$ & 5 & 640 \\
7 & 640 & 2000 & 160 & 640 & 40 & 40 & 80 & 20 & $<10$ & 80 & 1280 \\
8 & 320 & 1000 & 80 & 640 & 40 & 40 & 160 & 20 & $<10$ & 20 & $>1280$ \\
9 & 40 & 625 & 40 & 320 & 40 & 20 & 80 & 160 & $<10$ & 20 & $>1280$ \\
10 & 640 & 500 & 320 & $>1280$ & 40 & 80 & 640 & 320 & $<10$ & 20 & $>1280$ \\
11 & 640 & 2000 & 640 & 640 & 40 & 80 & 320 & 320 & $<10$ & 20 & $>1280$ \\
12 & 640 & 2000 & 640 & $>1280$ & 40 & 80 & 320 & 320 & $<10$ & 20 & $>1280$ \\
13 & 640 & 2000 & 320 & 1280 & 40 & 40 & 320 & 320 & $<10$ & 20 & $>1280$ \\
14 & 640 & 2000 & 320 & $>1280$ & 40 & 40 & 160 & 320 & $<10$ & 20 & $>1280$ \\
15 & 640 & 2000 & 320 & 1280 & 40 & 80 & 320 & 160 & $<10$ & 20 & $>1280$ \\
16 & 640 & 2000 & 320 & 1280 & 40 & 40 & 320 & 160 & $<10$ & 20 & $>1280$ \\
17 & 640 & 2000 & 640 & $>1280$ & 20 & 40 & 320 & 160 & $<10$ & 20 & $>1280$ \\
18 & $<40$ & $<40$ & 40 & 20 & 20 & $<5$ & $<5$ & $<20$ & $<10$ & 40 & $>1280$
\end{tabular}

* Abbreviations: Pc, penicillin; $\mathrm{Cb}$, carbenicillin; $\mathrm{Nm}$, neomycin; Sm, streptomycin; Nal, nalidixic acid; Km, kanamycin; Gm, gentamycin; Tc, tetracycline; Mc, minocycline; $\mathrm{Cm}$, chloramphenicol; PolyB, polymyxin B.

$\dagger$ Code number given for this study (see Table 1): strains 1 to 6 were from clinical sources; strains 7 and 8 were isolated from hospital equipment; strains 9 to 18 were of plant or soil origin.

\section{DISCUSSION}

Epidemiological surveillance of $P$. cepacia has not been possible previously as strains from clinical sources could not be distinguished from those from plants and soil (Sinsabaugh \& Howard, 1975; Snell et al., 1972). However, our results show that these strains can be separated into two distinct groups, based on bacteriocin production, maceration of onion slices, hydrolysis of low pH pectate agar and plasmid profile.

Bacteriocin production is more stable as an epidemiological marker than bacteriocin sensitivity (Farmer, 1972a,b) and has been used as an epidemiological tool for a number of Gram-negative bacteria (Abbott \& Shannon, 1958; Farmer, 1972a, $b$; Gillies \& Govan, 1966; Stouthamer \& Tieze, 1966; Vidaver et al., 1972). The production patterns obtained with the Hines strains as indicators clearly allowed differentiation between the plant isolates of $P$. cepacia and those of clinical origin. Interestingly, the $P$. multivorans strain also inhibited the Hines isolates and, therefore, belongs to the same group as the plant isolates.

The onion slice test for soft rotting of tissue also differentiated the two groups, the clinical isolates having little or no activity. Endopolygalacturonase from $P$. cepacia in diseased onions has a pH optimum between 4.4 and 4.6 (Ulrich, 1975). The $\mathrm{pH}$ dependence of the activity of the isolates tested here was also evident; all plant strains had moderate activity after $24 \mathrm{~h}$ at $\mathrm{pH} 4.9$ whilst only one isolate had activity at $\mathrm{pH} 6.9$. The clinical strains, with two exceptions, showed, at most, only a trace of activity at the lower $\mathrm{pH}$ and none at the higher.

Although strains of $P$. cepacia can be differentiated by their pectolytic activity, isolates of both types proved equally toxic to mice; the $\mathrm{LD}_{50}$ for plant strains averaged to $3.7 \times 10^{8}$, and that for clinical strains was $3.9 \times 10^{8}$. Similarly, resistance to antibiotics was not significantly different between the two groups of isolates. The levels of resistance, in several instances, were in excess of normal levels of chromosomal resistance. In particular, the resistance to tetracycline (m.i.c. $320 \mu \mathrm{g} \mathrm{ml}^{-1}$ ) was much higher than previously recorded for strains of $P$. aeruginosa, $P$. fluorescens and P. putida (Shipley \& Olsen, 1974) and this value 


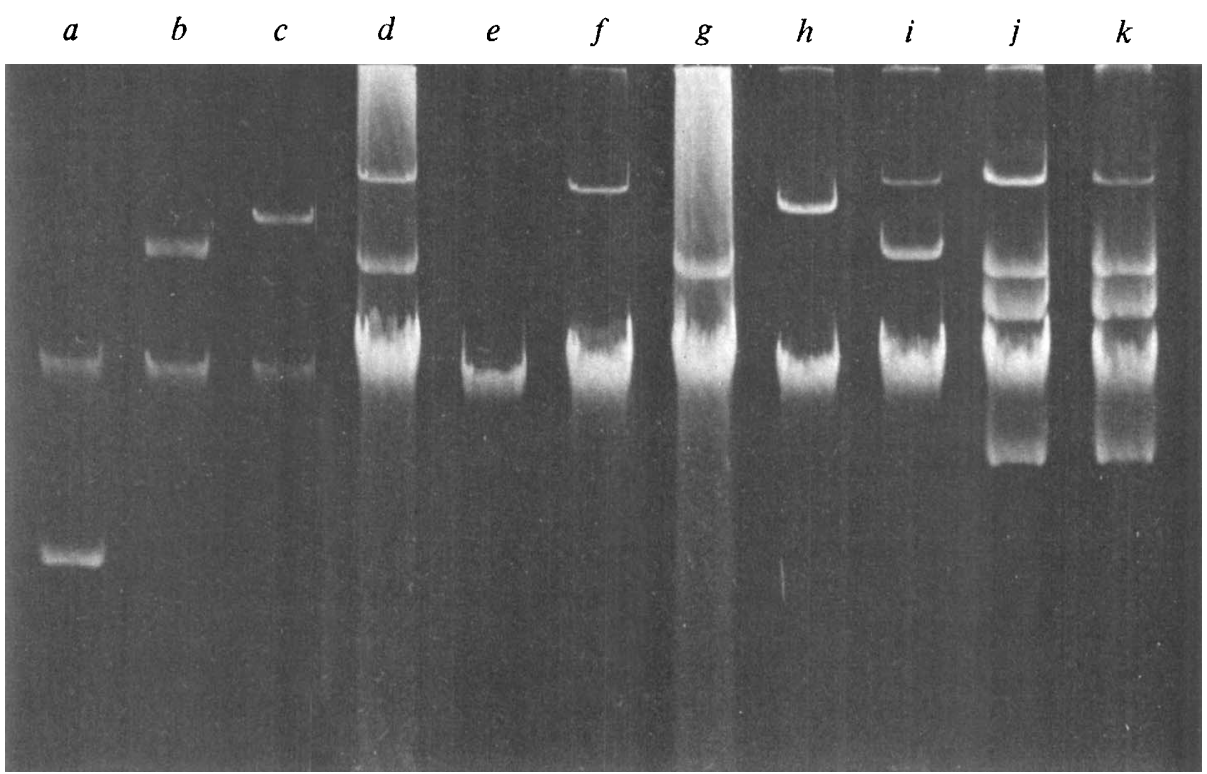

Fig. 1. Agarose gel electrophoresis of ethanol-precipitated plasmid DNA from cleared lysates of $P$. cepacia of clinical origin and of $E$. coli containing reference plasmids: (a) E. coli J53(RSF1030), $5.5 \times 10^{6}$ daltons (lower band), chromosomal DNA (upper band); (b) E. coli J53(RP4), $34 \times 10^{6}$ daltons; (c) E. coli J53(R1drd19), $62 \times 10^{6}$ daltons; (d) P. cepacia B5912, $105 \times 10^{6}$ and $30 \times 10^{6}$ daltons; (e) P. cepacia B6566, none; $(f) P$. cepacia ATcC $25609,105 \times 10^{6}$ daltons; $(g) P$. cepacia B5910, $30 \times 10^{6}$ daltons; $(h) P$. cepacia B4648, 63.5 $\times 10^{6}$ daltons; $(i) P$. cepacia $\mathrm{B} 4345,105 \times 10^{6}$ and $41 \times 10^{6}$ daltons; $(j) P$. cepacia Hines no. $1,105 \times 10^{6}, 33 \times 10^{6}, 23 \times 10^{6}$ and $9 \times 10^{6}$ daltons; (k) $P$. cepacia Hines no. 2, $105 \times 10^{6}, 33 \times 10^{6}, 23 \times 10^{6}$ and $9 \times 10^{6}$ daltons. Chromosomal DNA migrated to the same position for all strains.

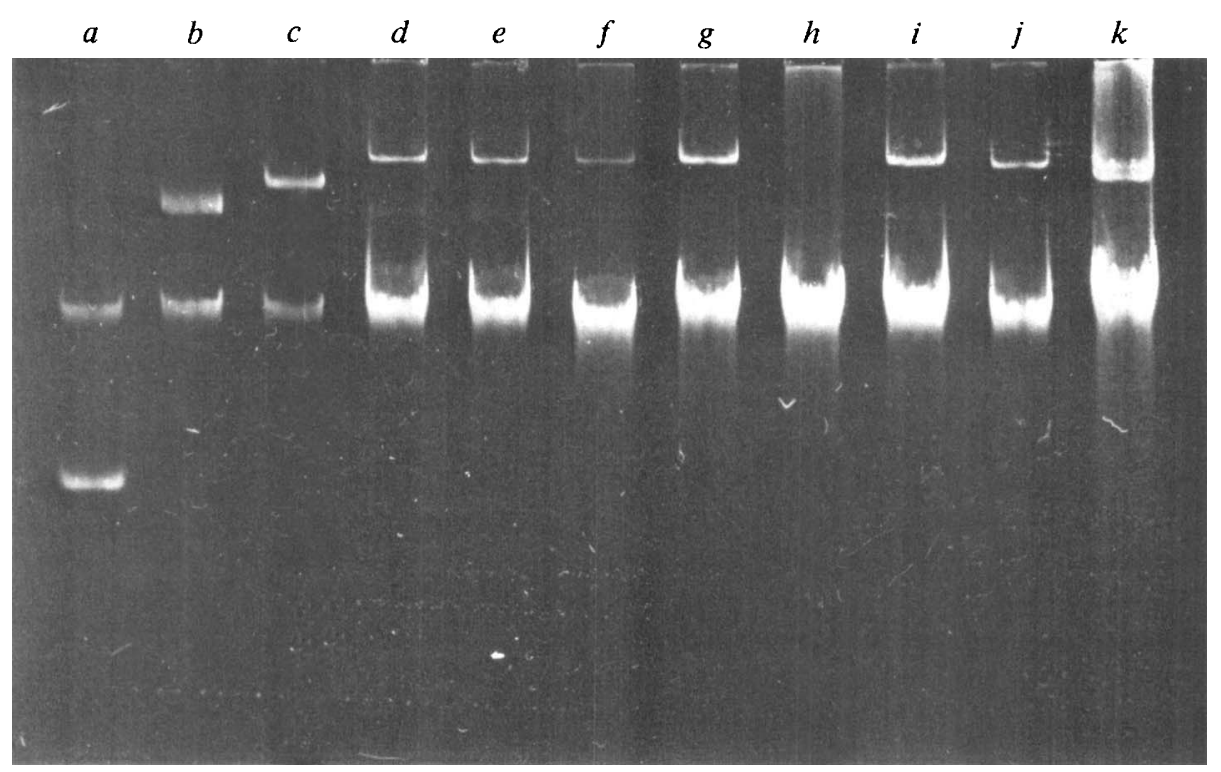

Fig. 2. Agarose gel electrophoresis of ethanol-precipitated plasmid DNA from cleared lysates of $P$. cepacia of plant and soil origin and of $E$. coli containing reference plasmids: $(a) E$. coli J53(RSF1030), 5.5 $\times 10^{6}$ daltons (lower band), chromosomal DNA (upper band); (b) $E$. coli J53(RP4), $34 \times 10^{6}$ daltons; (c) E. coli J53(R1drd19), $62 \times 10^{6}$ daltons; (d) P. cepacia 74-34, $120 \times 10^{6}$ and $45 \times 10^{6}$ daltons; (e) $P$. cepacia $64-22,120 \times 10^{6}$ and $45 \times 10^{6}$ daltons; $(f) P$. cepacia ATCC 25416 , $120 \times 10^{6}$ daltons; $(g)$ P. cepacia ATCC $10856,120 \times 10^{6}$ daltons; $(h) P$. multivorans atcC 17759 , $13 \times 10^{6}$ daltons; (i) P. cepacia $71-22,120 \times 10^{6}$ daltons, $(j)$ P. cepacia $72-60,120 \times 10^{6}$ daltons; (k) $P$. allicola ATCC 19302, $120 \times 10^{6}$ and $90 \times 10^{6}$ daltons. Chromosomal DNA migrated to the same position for all strains. 
is in keeping with resistance being determined by R factors (Shipley \& Olsen, 1974; Lacey, 1973). By analogy with the results and conclusions of Asheshov (1975) - who found that the tetracycline resistance determinant was plasmid borne in strains inducibly resistant to tetracycline, but sensitive to minocycline-we consider that the tetracycline resistance may be plasmid determined. Indeed, agarose gel analysis showed the presence of one or more plasmids of differing size in 15 out of 16 strains examined.

It is suggested that a combination of bacteriocin production and either the pectate gel test or the onion slice soft rot test would assist both clinicians and plant pathologists in determining the origin of $P$. cepacia isolates.

C.F.G. was supported by a predoctoral fellowship granted by the Ford Foundation. This work was supported, in part, by USDA-regional research funds for project NC-135. Published as Paper Number 5545, Journal Series, Nebraska Agricultural Experiment Station.

\section{REFERENCES}

Aвbott, J. D. \& Shannon, R. (1958). A method of typing Shigella sonnei using colicine productic $n$ as a marker. Journal of Clinical Pathology 11, $71-77$.

AsHeshov, E. H. (1975). The genetics of tetracycline resistance in Staphylococcus aureus. Journal of General Microbiology 88, 132-140.

Ballard, R. W., Palleroni, N. J., Doudoroff, M., Stanier, R. Y. \& MANDel, M. (1970). Taxonomy of the aerobic pseudomonads: Pseudomonas cepacia. $P$. marginata, $P$. alliicola and $P$. caryophylli. Journal of General Microbiology 60, 199214.

Bassell, D. C. J., Stokes, K. J. \& Thomas, W. R. G. (1970). Wound infection with Pseudomonas multivorans. Lancet i, 1188-1191.

BERK, R. S. (1977). Experimental mouse infections caused by Pseudomonas aeruginosa. In Microbiology -1977 , pp. 169-172. Edited by D. Schlessinger. Washington, D.C.: American Society for Microbiology.

BurkHOLder, W. H. (1950). Sour skin, a bacterial rot of onion bulbs. Phytopathology 40, 115-117.

Cuppels, D. \& Kelman, A. (1974). Evaluation of selective media for isolation of soft rot bacteria from soil and plant tissue. Phytopathology 64, $468-475$.

Currier, T. C. \& Nester, E. W. (1976). Isolation of covalently closed circular DNA of high molecular weight from bacteria. Analytical Biochemistry 76, 431-441.

Dailey, R. H. \& Benner, E. J. (1968). Necrotizing pneumonitis due to the pseudomonad Eugonic Oxidizer - Group 1'. New England Journal of Medicine 279, 361-362.

FARmer, J. J. (1972a). Epidemiological differentiation of Serratia marcescens: typing by bacteriocin production. Applied Microbiology 23, 218-225.

FARMER, J. J. (1972b). Epidemiological differentiation of Serratia marcescens: typing by bacteriocin sensitivity. Applied Microbiology 23, 226-231.

GilARDI, G. L. (1971). Antimicrobial susceptibility as a diagnostic aid in the identification of nonfermenting gram-negative bacteria. Applied Microbiology 22, 821-823.
Gillies, R. R. \& Govan, J. R. W. (1966). Typing of Pseudomonas pyocyanea by pyocine production. Journal of Pathology and Bacteriology 91, 339-345.

HaAG. W. L. \& Vidaver, A. K. (1974). Purification and characterization of syringacin 4-A, a bacteriocin from Pseudomonas syringae 4-A. Antimicrobial Agents and Chemotherapy 6, 76-83.

Hildebrand, D. C. (1971). Pectate and pectin gels for differentiation of Pseudomonas sp. and other bacterial plant pathogens. Phytopathology 61, 1430-1436.

Hugh, R. \& Leifson, E. (1953). The taxonomic significance of fermentative versus oxidative metabolism of carbohydrates by various gramnegative bacteria. Journal of Bacteriology 66, 24-26.

Jonsson, V. (1970). Proposal of a new species Pseudomonas kingii. International Journal of Systematic Bacteriology 20, 255-257.

LACEY, R. W. (1973). Genetic basis, epidemiology and future significance of antibiotic resistance in Staphylococcus aureus. A review. Journal of Clinical Pathology 26, 899-913.

Phillips, I., Eykyn, S., Curtis, M. A. \& Snell, J. J. S. (1971). Pseudomonas cepacia (multivorans) septicaemia in an intensive care unit. Lancet i, 375-377.

REeD, L. J. \& Muench, H. (1938). A simple method of estimating fifty percent endpoints. American Journal of Hygiene 27, 493-497.

Shipley, P. L. \& Olsen. R. H. (1974). Characteristics and expression of tetracycline resistance in gram-negative bacteria carrying the Pseudomonas R factor RP1. Antimicrobial Agents and Chemotherapy 6, 183-190

Sinsabaugh, H. A. \& Howard, G. W. (1975). Emendation of the description of Pseudomonas cepacia Burkholder (Synonyms: Pseudomonas multivorans Stanier et al., Pseudomonas kingae Jonsson; EO-1 group). International Journal of Systematic Bacteriology 25, 187-201.

Smith, R. N., Gordon, R. E. \& Clar K, F. E. (1952). Aerobic Spore-forming Bacteria, Agriculture Monograph no. 16, p. 42. Washington, D.C.: U.S. Department of Agriculture.

Snell, J. J. S., Hill, L. R., Lapage, S. P. \& Curtis, 
M. A. (1972). Identification of Pseudomonas cepacia Burkholder and its synonymy with Pseudomonas kingii Jonsson. International Journal of Systematic Bacteriology 22, 127-138.

Stanier, R. Y., Palleroni, N. J. \& Doudoroff, M. (1966). The aerobic pseudomonads: a taxonomic study. Journal of General Microbiology 43, 159 271.

Stouthamer, A. H. \& Tieze, G. A. (1966). Bacteriocin production by members of the genus Klebsiella. Antonie van Leeuwenhoek 32, 171-182.

Taplin, D., Bassett, D. C. J. \& Mertz, P. M. (1971). Foot lesions associated with Pseudomonas cepacia. Lancet ii, 568-571.

Thornley, M. J. (1960). The differentiation of Pseudomonas from other Gram-negative bacteria on the basis of arginine metabolism. Journal of Applied Bacteriology 23, 37-52.

Ulrich, J. M. (1975). Pectic enzymes of Pseudomonas cepacia and penetration of polygalacturonase into cells. Physiological Plant Pathology 5, 37-44.

VIDAVER, A. K. (1967). Synthetic and complex media for the rapid detection of fluorescence of phytopathogenic pseudomonads: effect of the carbon source. Applied Microbiology 15, 1523-1524.

Vidaver, A. K., Mathys, M. L., Thomas, M. E. \& SChuster, M. L. (1972). Bacteriocins of the phytopathogens Pseudomonas syringae, P. glyci$n e a$ and $P$. phaseolicola. Canadian Journal of Microbiology 18, 705-713. 